\title{
Identifying Strategies to Minimize Intergenerational Conflict in Workplace
}

\section{Rasolofomanana Tahiry Nantenain Jemima ${ }^{1}$ and E. Kusumadmo ${ }^{2}$ \\ ${ }^{1,2}$ Universitas Atma Jaya Yogyakarta \\ rtahiryjemima@yahoo.com}

\begin{abstract}
This study was conducted to identify strategies to minimize intergenerational conflict in workplace in an e-commerce company in Madagascar. This company is made up of three generations of people who is different in many ways that often lead conflict in workplace.

In this study, 125 out of 150 questionnaires were returned to the researcher to be analyzed and interviews were conducted with four people. The data were analyzed by using NVivo 8.

The finding of this study indicates that to minimize intergenerational conflicts: managers should have more understanding on what their employee's needs and expectations; they must familiarize themselves with them. Establishing internal communication that value everyone is a must to solve intergenerational concern. Training is useful to strengthen team cohesion and mentorship is to break through barriers by encouraging employees of different generations to connect each other and setting compromise improve collaborations level among employees.

Keywords: conflict management, intergenerational conflict, multigenerational workplace.
\end{abstract}

\begin{tabular}{ll}
\hline JEL & $:$ M12, M14 \\
DOI & $: 10.24002 /$ kinerja.v22i2.2127
\end{tabular}

Received : 1/12/2019 Reviewed: 2/6/2019 Final Version: 2/18/2019

\section{INTRODUCTION}

Workforce has become more diverse, not only in terms of ethnicity, gender, and culture but also in terms of age. With these changes in employee's demographics, today's workplace consists of three generations, sometimes four: 
traditionalists, baby boomers, generation $\mathrm{X}$ and millennial also known as generation $Y$. Each of these generations grew up experiencing significantly different events that have shaped their values and perception of work. Multigenerational work groups bring a varied set of complementary skills to a workplace. These differences can be beneficial, enriching the workplace with complementary skills; however they present challenges as well. The diversity in the workplace is growing with the three generations working side by side and causes conflicting issues that affect the efficiency of the work flow among co-workers or management structure and disrupts the effectiveness of fulfilling corporate goals.

An e-commerce company in Madagascar is experiencing a dramatic decline in productivity due to intergenerational conflict in workplace, yet this company is considered to have a very high competitiveness because of its multicultural workforce. This company is one of the companies giving wide opportunity for young people to work; even fresh graduate is welcomed in order to have the best young talent. However having these young people in their workplace turned out to be their biggest challenge. Interestingly enough, how the impact of the conflict decreased the productivity from very high to down in few years only.

\section{LITERATURE REVIEW}

\subsection{Generational Cohort}

The term generation has been defined in numerous ways. One of the most accepted definitions refers a generation as "a group of people or cohorts who share birth years and experiences as they move through time together" (Kupperschmidt, 2000:66). The collective experiences of members of a group within a designated span of birth years shape value sets and attitudes among members of the generation. Thus, generations, not clear cut characteristic shifts. Life experiences, in addition to personal predispositions, shape values and attitudes that translate to the work environment. Today, the multigenerational workforce is mainly comprised of three groups defined by years-born: Baby boomers (born 1946 - 1964), Generation X-ers (born 1965-1980), and Millennial (born1981-1999).

\subsection{Baby Boomers}

This generation is referred to as the Baby Boom, because of the extra seventeen million babies born during that period relative to previous census figures (O'Bannon, 2001). Boomers are presently the strongest generation in the workplace. This is due to their "seniority" as defined by years in the workplace, gained experience to self-promote themselves, and their authoritative growth into positions of power. The Baby boomer's area unique generation that shaped the workforce and is a highly regarded and a respected generation due to their loyalty and strong work ethic (Wesner \& Miller, 2008). 


\subsection{Generation $X$}

Generation X - born between 1965- 1980 may be best known as the former "latch-key kids", growing up less supervised or doted upon than the Boomers. Xers' independence is derived from their childhood years, many times absent of parents who both worked long hours. Perceiving their Boomer counterparts to be workaholics, Gen Xers are among the first to change demands prevent their ability to attend too family and personal lives (Ernest \& Young LPP, 2013).

\subsection{Millennial/Generation $Y$}

Generation $\mathrm{Y}$ is the largest generation in history with approximately 79.8 million members, exceeding the large numbers of the Baby Boomer generation (Robert Half International, 2008a). Atkinson (2008) explain Generation Y was shaped by the following events: street murder, muggings, school shootings, terrorist attacks, war, and corporate ethical violations such an Enron. Millennial are naturally taken by the concept of equity across the board in the workplace.

\subsection{Multigenerational Workforce}

A multigenerational workforce refers to the generational cohorts present within organizations and includes Baby boomers, Generation X and Millennial. (Allah 2011; Gargoline 2012). A study conducted by Randstad (2008) shows what each generation currently feels about the workplace, but most importantly what they would like to see different. Explaining that "...Gen Y, Gen X, Baby Boomers, and Mature have different definitions of experience, sharing and no consistent way to understand what each has to offer" (p.20).

\subsection{Conceptual Framework}

\subsubsection{Work Value of Each Generation}

George and Jones (1997) defined work values as a framework for what is important to a person in the organizational environment and what is fundamentally right and wrong. This framework develops over time through an individual's experiences and allows an understanding of the type of actions which are broadly desirable and undesirable. Work values can be defined as permanent guides for experience, allowing various actions to be evaluated and meaning to be given to particular work experiences.

\subsubsection{Work Value of Baby Boomers}

Common perceptions of Baby Boomers often include their self-appointment as moral authorities. In the workplace, Boomers are advocates for being "teamplayers", a value on physical presence at work and strong organizational commitment and loyalty (Ernest \& Young LLP, 2013). Lancaster and Stillman (2002) noted that, on average, members of the Boomer generation tend to build strong 
careers in one organization, recognizing constant job changes as a poor career move.

\subsubsection{Generation $X$}

Individualism over collectivism tends to be favored by Generation X, in contrast to Baby Boomers. This generation has a preference to work for organisations which value skills and productivity rather than tenure. This independence and autonomy may be why self- employment and creative roles tend to be favored by the Xers (Eslinger, 2001; Zemke et al., 2000). Generation X generally lack reverence for authority because they've seen many authority figures falter, so they place a relatively low value on the hierarchical status of an individual.

\subsubsection{Millennial}

Millennial are often perceived as ladder jumping in the workplace expecting promotions, without the years of work and experience that Boomers amassed, in order to climb professional ladders (Groggan, 2016).

\subsubsection{Expected Reward by Baby boomers}

Boomers also realizing their need to maintain marketable skills and possibly re-create themselves for the remainder of their working years. The opportunity to take an extended period of time off from a job and return at a later date will become a hotly valued reward. (Reynold L.A 2005).

\subsubsection{Expected rewards by Generation $X$}

Generation Xers place skill development at the top of their list of valued rewards. Flextime, job-sharing and telecommuting are highly valued rewards; Xers also value being supervised by managers who focus on results, as opposed to "face time" or what Xers perceive as corporate "games". Authentic, candid and down-toearth behaviors are what this group looks for in employment situations. (Reynold L.A 2005)

\subsubsection{Expected Rewards by Millennial}

Millennial's assumption about the work world is that it will offer challenges and learning opportunities, as well as work/life balance. If an employer fails to offer such an environment and set of rewards. Their programmed life has made them able to perform several tasks, to correctly assume several jobs at the same time. They need flexibility to cope with all their activities. Companies that figure out how to adapt to the expectations of generation $Y$ and thrive on their innovative and technosavvy contributions will win in the talent wars and excel on the global competition for new ideas. (Reynold L.A 2005)

\subsubsection{Conflict}

The shift in the demographics in terms of multi-generations at workplace brings in a lot of diversity. These differences bring lot of complexities as each generation 
has their own expectations of the workplace and hence perspectives differ which create conflicts at workplace. Murphy, Gibson, and Greenwood (2010) describe the situation as follows: "the difficulties of managing an age-diverse workforce, with its potential for conflict, are widely accepted".

\subsubsection{Resolution of Workplace Conflict}

Maravelas (2005) stated, "People have strong needs for a sense of belonging. When workplaces don't provide an opportunity for respect, camaraderie, and attachment, individuals make their emotional investment in unions, local bars, gangs, recreational activities, home-based businesses, faith communities, or families" (pp. 152-153). This sense of belonging cannot be maximized if the employee is embroiled in conflict turmoil.

According to Meyer (2004), there are five conflict-handling strategies: integrating, compromising, obliging, avoiding, and forcing. Sikes et al. (2010) and Jones (2009) classified these as five generic approaches to intergroup conflict and labeled them dominating, accommodating, problem solving, avoiding, and compromising. The integrating style (or problem solving approach) of conflict handling involves problem solving and collaboration, and centers on all parties sharing information and working towards a satisfactory goal. Sikes et al. (2010) noted that this is often the ideal approach due to the collaborative aspect and the merging of insights, experience, perspective, and knowledge. Organizations should embrace cultural differences and utilize them to enhance their group performance (Herring, 2009; Ottaviano, 2006; Palmer \& Varner, 2007).

\section{METHODOLOGY}

This research is a descriptive case study focusing on generational conflict within an e-commerce company in Madagascar. In case studies, the case is the individual, the group, the organization, the event, or the situation the researcher is interested in. The idea behind a case study is that in order to obtain a clear picture of a data collection. Along these lines, one may define a case study as research strategy that involves an empirical data collection (Yin, 2009). Data was collected by completing interviews and sharing questionnaire. The data collected were analyzed by using Nvivo8.

\section{RESULT AND DISCUSSION}

Throughout the data analysis, five strategies were discovered to addressing the strategies to coordinate the work value of each generation in order to minimize conflict in workplace. 


\subsection{Priorities}

Priorities of each generation includes their work value, as well as their expectations at work, whether personal or towards their managers. Managers should then have a high level of understanding on why each generation value different things and expect different things. J. W. Gibson et al. (2009) believed that when leading and interacting with different generations, managers should consider generational differences in values, beliefs, and behaviors.

\subsection{Communication}

The use of effective internal communication to engage their employees, which mean that each mode of communication must be adapted to the person to whom it is addressed. A good strategy would include incorporating the communication preferences of all generations in order to ensure the flow of information. Open communication should be encouraged as a means of resolving differences in interpretations and perceptions. The commonalities between the employees involved in the conflict, despite their different cultures, should be emphasized as part of the resolution strategy and differences minimized (Sikes et al., 2010).

\subsection{Training}

Training is effective in managing intergenerational conflict, it is a useful tool to explain to employees why their colleagues act in such a way or why the change of leadership style in the company should be radical. Training is also very necessary for learning and preparing everyone for change. The most suitable form of training for a multigenerational workplace is team building, it is a good way to link generations, to exchange in a framework of collective cohesion that dissociates itself from the professional environment. This type of training allows employees to develop strategies to address conflict before it occurs (Sikes et al., 2010).

\subsection{Mentorship}

Multigenerational mentoring breaks through barriers by encouraging employees of different generations to connect each other on a more meaningful level. A generationally based mentoring program designed to spread institutional knowledge, career progression, adoption of policies, management styles, and visibility to all employees can cultivate contributions from the most talented employees from all four generations (Hershatter \& Epstein, 2010).

\subsection{Compromise}

All employees want to do well and help the company that is why; a compromise will be an effective strategy to resolve conflict. This is often the best resolution strategy, according to Wienclaw (2015), for "situations in which there is little possibility of mutual gain through problems solving, both parties have equal power, and there are time pressures to settle the conflict" (p. 748). 


\section{CONCLUSION}

Surely, everyone is different, even people of the same generation can be different. However, these differences should not be an obstacle for a company. Intergenerational management requires a look without judgment. No generation is better than others. Intergenerational management is a response to the challenges of knowledge transfer, team cohesion and integration of Generation $Y$ in companies. This means working together people who do not necessarily want to cooperate; by creating spaces for dialogue and sharing.

Certainly, there will always be refractory to change: some baby boomers close to retirement having nothing to gain some generation $X$ conservatives who exclude themselves from the system. But the majority of the employees have everything to gain from these new working devices: to build a collective performance makes it possible precisely to make fruitful the individual intelligences. Most companies understand this without realizing the scope or the urgency. Organizations must not adapt, they must transform themselves, take the multigenerational bull by the horns in a globalized world where everything goes faster every day.

\section{REFERENCE}

Allah, H. B. 2011. The influence of multigenerational cohorts on organizational leadership: A phenomenological study (Doctoral dissertation). [online] Available from ProQuest Dissertation and Theses database.

Eslinger, M. R. 2001. A multi-generational workplace: The differentiation of generations by the work values they possess. Dissertation Abstracts International, 1297A.

Ernest \& Yong LLP. 2013. Younger managers rise in the ranks: survey quantifies management shift and reveals challenges, preferred workplace perks, and perceived generational strengths and weaknesses. [online] Available at http://www.multivu.com/mnr/63086-ernst-and-young-llp-research-younger managers- rise-in-the-ranks

George, J.M., \& Jones, G.R. 1997. Experiencing work: Values, attitudes, and moods. Human Relations, 50(4), pp. 393-416.

Gibson, J. W., Greenwood, R. A., \& Murphy, E. F., Jr. 2009. Generational differences in the workplace: Personal values, behaviors and popular beliefs. Journal of Diversity Management, 4(3), pp. 1-8. 
Groggan, B. 2016. The keys to working well with millennial. [online] Available at http://modernae.com/the-keys-to-working-well-with-millennials/

[Accessed December 28, 2016].

Herring, C. 2009. Does diversity pay? Race, gender, and the business case for diversity. American Sociological Review, 74(2), pp. 208-224.

Jones, C. 2009. Sort it out! Nursery World, 109(4200), pp. 24-25.

Kupperschmidt, B.R. 2000. Multigenerational employees: Strategies for effective management. The Health Care Manager, 19, pp. 65-76

Lancaster, L.C., \& Stillman, D. 2002. When generations collide: Traditionalists, Baby Boomers, Generation Xers, Milennials: Who they are, why they clash, how to solve the generational puzzle at work. New York: Harper Collins.

Maravelas, A. 2005. How to reduce workplace conflict and stress: How leaders and their employees can protect their sanity and productivity from tension and turf wars. Franklin Lakes, NJ: Career Press.

Meyer, S. 2004. Organizational response to conflict: Future conflict and work outcomes. Social Work Research, 28(3), pp. 183-190.

Nvivo qualitative data analysis software. 2008. QSR International Pty Ltd., Version 8. Melbourne: Australia.

Ottaviano, G. 2006. The economic value of cultural diversity: Evidence from US cities. Journal of Economic Geography, 6(1), pp. 9-44.

O'Bannon, G. 2001. Managing our future: The generation $X$ factor. Public Personnel Management, 30, pp. 95-109.

Palmer. T., \& Varner, I. 2007. A comparison of the international diversity on top management teams of multinational firms based in the United States, Europe, and Asia: Status and implications. Singapore Management Review, 29(1), pp. 1-30.

Randstad. 2008. The Randstad USA World of Work. [Online] Available at http://www.harrisinteractive.com, [Accessed December 23, 2008].

Reynolds, L.A. 2005. Communicating total rewards to the generations. Benefits Quarterly (Second Quarter), pp.13-17.

Robert Half International. 2008a. The EDGE Report. [Online] Available at http://www.rhi.com [Accessed December 23, 2008].

Sikes, B.,Gulbro, R., \& Shonesy, L. 2010. Conflict in work teams: Problems and solutions. Allied Academies International Conference: Proceedings of the Academy of Organizational Culture, Communications \& Conflict, 15(1), pp. 15-19. 
Wienclaw, R. A. 2015. Teams \& team building. Research starters business.

Wesner, M.S., \& Miller, T. 2008. Boomers and Millennial have much in common. Organization Development Journal, 26(3), pp. 89-96.

Yin, R. 2009. Case Study research: Design and Methods, 4th Edition. Thousand Oaks, CA: Sage Publications

Zemke, R., Raines, C., \& Filipczak, B. 2000. Generations at work: Managing the clash of Veterans, Boomers, Xers and Nexters in your workplace. New York: Amacom. 